\title{
PENERAPAN METODE BAYES DALAM MENGESTIMASI PREMI RISIKO PADA ASURANSI PENYAKIT KRITIS
}

\author{
Sisilia Martina Utami Agustini ${ }^{1 \S}$, I Nyoman Widana ${ }^{2}$, Ni Ketut Tari Tastrawati ${ }^{3}$ \\ ${ }^{1}$ Program Studi Matematika, Fakultas MIPA - Universitas Udayana [Email: sisiliamartina23@gmail.com] \\ ${ }^{2}$ Program Studi Matematika, Fakultas MIPA - Universitas Udayana [Email: widana@unud.ac.id] \\ ${ }^{3}$ Program Studi Matematika, Fakultas MIPA - Universitas Udayana [Email: tastrawati@unud.ac.id] \\ ${ }^{\S}$ Corresponding Author
}

\begin{abstract}
The high number of critical illness cases and the rising medical cost affect the number of insurance claimed. It can be a problem for the insurance company in estimating future claim trend to decide the risk premium cost, so that we need a method to solve the problem which is called Empirical Bayes Credibility Theory (EBCT). Based on that information, the goal of this research is estimating the risk premium cost for critical illness cases using EBCT method. In this research, a large simulation of the expected claim data of critical illness policyholders is used, which are grouped by age and gender. In processing data by applying the EBCT method, the credibility factor is determined first, then the size of the risk premium can be estimated, with the calculation results obtained by a different estimate of the risk premium for each age group based on gender.
\end{abstract}

Keywords: Critical Illness, EBCT, Risk Premium

\section{PENDAHULUAN}

Menurut data WHO (2013), penyakit kritis seperti penyakit jantung, kanker, dan stroke adalah penyebab kematian utama didunia. Di Indonesia khususnya di Provinsi Bali, menurut hasil Riset Kesehatan Dasar (2018) prevalensi ketiga penyakit kritis tersebut cukup tinggi. Prevalensi penyakit jantung, kanker dan stroke berdasarkan terdiagnosis dokter secara berurutan sebesar 1,3\%, 2,0\%, dan 10,5\%. Tidak hanya angka kejadian penyakit kritis yang masih tinggi, biaya perawatan kesehatan juga meningkat pesat selama beberapa dekade terakhir (Sukono, et al 2017). Hal-hal yang perlu diwaspadai, penyakit kritis merupakan kejadian tak terduga sehingga seseorang yang didiagnosis menderita penyakit kritis secara finansial memerlukan perlindungan. Oleh karena itu, peran perusahaan asuransi sangat diperlukan.

Salah satu jenis asuransi yang dapat membantu seseorang yang berisiko mengidap penyakit kritis adalah asuransi jiwa dengan produk asuransi tambahan berupa asuransi untuk penyakit kritis. Menurut Mueller \& Spencer (2012), asuransi penyakit kritis memberikan tunjangan tunai langsung kepada

tertanggung ketika didiagnosis dengan penyakit kritis.

Dengan tercatatnya angka kejadian penyakit ktitis yang masih tinggi, dan biaya perawatan terus meningkat, jumlah klaim dari tahun ke tahun meningkat (Sheta \& Eldeen, 2012). Ini merupakan masalah bagi perusahaan asuransi dalam memperkirakan tren klaim di masa depan untuk menentukan harga premi risiko (premi netto). Premi risiko atau premi netto adalah premi yang harus dibayarkan pemegang polis atau tertanggung berdasarkan tingkat mortalita dan perkiraan tingkat suku bunga, sedangkan tingkat biaya tidak dipergunakan (Sembiring, 1986). Penentuan premi risiko harus diperhitungkan, agar perusahaan asuransi tidak mengalami kerugian (Pham, 2014).

Terdapat suatu teori yang biasa digunakan oleh aktuaris dalam mengestimasi harga premi berdasarkan pengalaman klaim di masa lalu, yaitu teori kredibilitas (Herzog, 1996). Pada teori kredibilitas, terdapat banyak jenis metode dengan berbagai tingkat kompleksitas telah dikembangkan untuk dapat digunakan dalam mengestimasi harga premi di masa depan, salah satunya Empirical Bayes Credibility Theory 
(EBCT) atau Teori Kredibilitas Bayes Empiris (Chukwudum, 2018). Satu keuntungan utama dari metode EBCT yang disampaikan oleh Chukwudum (2018) data jaminan atau agunan dapat merepresentasikan data dan risikonya tanpa perlu membuat asumsi terkait distribusi data jaminan atau agunan, dan data mengenai prior-nya.

Metode EBCT pernah diterapkan oleh Chukwudum (2018) dalam penelitiannya untuk mengestimasi harga premi risiko asuransi bisnis tahun 2014 di Nigeria dimana lima kelas risiko yaitu portofolio kebakaran, kecelakaan, mesin, kelautan, serta minyak dan gas diamati. Pada penelitian tersebut hasil estimasi harga premi risiko digunakan untuk memberikan gambaran bagi perusahaan asuransi terkait cadangan yang perlu disiapkan perusahaan asuransi dalam mengantisipasi kemungkinan klaim yang lebih banyak. Lebih lanjut lagi, penelitian serupa pernah dilakukan oleh Sukono et al. (2017), dimana penelitian tersebut menghitung harga premi risiko asuransi jiwa, dengan menerapkan metode Bayes yang digabungkan dengan model risiko individu. Penelitian yang dilakukan oleh Sukono et al. (2017) tersebut dikhususkan untuk memberikan estimasi harga premi risiko asuransi jiwa pada pasien penyakit kanker dengan menggunakan data yang disimulasikan. Penelitian tersebut memiliki tujuan untuk menunjukkan penerapan metode Bayes dalam bidang asuransi.

Berdasarkan uraian diatas serta penelitianpenelitian terdahulu, penulis tertarik melakukan penelitian yang bertujuan untuk menentukan serta menginterpretasi estimasi premi risiko yang harus dibayarkan kepada perusahaan asuransi dengan menggunakan metode EBCT.

\section{METODE PENELITIAN}

\section{Jenis dan Sumber Data}

Data yang digunakan dalam penelitian ini adalah data simulasi besar eskpektasi klaim dari pemegang polis penyakit kritis, yang dikelompokkan berdasarkan umur dan jenis kelamin. Data simulasi diperoleh dengan mengadopsi data yang telah tersedia dalam jurnal Sukono et al. (2017)

\section{Metode Analisis Data}

Adapun langkah pertama yang dilakukan sebelum mengestimasi premi risiko yaitu mengestimasi besar ekspektasi klaim asuransi penyakit kritis setiap tahun selama 10 tahun, dimulai dari tahun 2005 sampai tahun 2014.

Selanjutnya, premi risiko diestimasi menggunakan metode Empirical Bayes Credibility Theory (EBCT) dengan langkahlangkah berikut :

1. Menghitung nilai rata-rata keseluruhan ekspektasi klaim kelompok polis dengan menggunakan persamaan $\hat{\mu}=\bar{X}=\frac{\sum_{i=1}^{r} \bar{X}_{i}}{r}$ dengan terlebih dahulu menghitung ratarata ekspektasi klaim dari masing-masing kelompok umur pria dan wanita dengan menggunakan persamaan $\bar{X}_{i}=\frac{\sum_{j=1}^{n} x_{i j}}{n}$

dimana $i=1,2,3, \ldots, r$ adalah kelompok amatan polis (dalam penelitian ini adalah kelompok umur) dan $j=1,2,3, \ldots, n$ adalah kolom tahun.

2. Mengestimasi nilai harapan dari variansi proses dengan menggunakan persamaan $\hat{v}=\frac{1}{r} \sum_{i=1}^{r} \widehat{v}_{l}$ dengan terlebih dahulu menghitung nilai variansi proses masingmasing kelompok umur pria dan wanita dengan menggunakan persamaan $\hat{v}_{i}=$ $\frac{1}{n-1} \sum_{j=1}^{n}\left(X_{i j}-\bar{X}_{l}\right)^{2}$

3. Mengestimasi variansi dari rata-rata keseluruhan ekspektasi klaim kelompok polis dengan menggunakan persamaan $\hat{a}=\frac{1}{r-1} \sum_{i=1}^{r}\left(\bar{x}_{i}-\bar{X}\right)-\frac{\bar{v}}{n}$

4. Mengestimasi harga premi risiko dengan menggunakan persamaan $\hat{C}=\hat{Z} \bar{X}_{i}+$ $(1-\hat{Z}) \mu \quad$ dengan terlebih dahulu menentukan parameter kredibilitas $\widehat{K}=\frac{\hat{v}}{\hat{a}}$ kemudian faktor kredibiltas $\hat{Z}=\frac{n}{n+\widehat{K}}$

Terakhir, menginterpretasi hasil estimasi premi risiko asuransi penyakit kritis.

Pada metode EBCT terdapat beberapa catatan penting terkait $\hat{Z}$ yang disampaikan oleh Chukwudum (2018), yaitu:

1. $\hat{Z}$ selalu bernilai antara 0 dan 1

2. $\hat{Z}$ adalah fungsi yang meningkat dari $n$. Hal ini menyiratkan bahwa jika terdapat lebih banyak data dibandingkan risiko, dengan demikian ini akan lebih diandalkan ketika perkiraan kredibilitas premi netto atau jumlah klaim dihitung.

3. $\hat{Z}$ dalah fungsi penurunan dari $\hat{v}$. Oleh karena itu jika $\hat{v}$ lebih tinggi nilainya dibandingkan dengan $\hat{a}$, maka data dari risiko akan lebih bervariasi jika dibandingkan dengan data dari risiko lain 
dalam kolektif (gabungan). Maka, data dari risiko akan kurang dapat diandalkan.

4. $\hat{Z}$ adalah fungsi yang meningkat dari $\hat{a}$. Oleh karena itu jika nilai $\hat{a}$ lebih tinggi dibandingkan dengan $\hat{v}$, akan terdapat lebih banyak variabilitas antara berbagai risiko dalam kolektif (gabungan) dan akan mengakibatkan lebih kecil kemungkinan bahwa risiko lain dalam kolektif akan menyerupai risiko yang menarik. Dengan demikian, lebih sedikit ketergantungan pada data dari risiko-risiko lain.

\section{HASIL DAN PEMBAHASAN}

Data besar ekspektasi klaim pemegang polis dari tahun 2005-2014 dari kelompok polis pria dan wanita disajikan pada Tabel 1 dan 2 .

Tabel 1. Besar Ekspektasi Klaim Selama 10 Tahun untuk Kelompok Polis Pria (Juta Rupiah/Tahun)

\begin{tabular}{|c|c|c|c|c|c|}
\hline Tahun & $\begin{array}{c}\text { Umur } \leq \\
30 \\
\text { Tahun }\end{array}$ & $\begin{array}{c}\text { Umur } 31 \\
-40 \\
\text { Tahun }\end{array}$ & $\begin{array}{c}\text { Umur 41 } \\
-50 \\
\text { Tahun }\end{array}$ & $\begin{array}{c}\text { Umur } \\
51- \\
60 \\
\text { Tahun }\end{array}$ & $\begin{array}{c}\text { Umur }> \\
60 \\
\text { Tahun }\end{array}$ \\
\hline 2005 & 0,425 & 0,662963 & 0,534375 & 0,740 & 0,662712 \\
\hline 2006 & 1,190 & 4,242963 & 2,244375 & 5,180 & 8,350169 \\
\hline 2007 & 2,380 & 2,519259 & 1,923750 & 2,812 & 6,096949 \\
\hline 2008 & 1,955 & 2,519259 & 2,030625 & 2,812 & 6,759661 \\
\hline 2009 & 1,615 & 2,784444 & 1,816875 & 2,960 & 7,157288 \\
\hline 2010 & 1,530 & 3,049630 & 1,603125 & 2,960 & 6,759661 \\
\hline 2011 & 1,275 & 3,182222 & 1,710000 & 2,812 & 6,892203 \\
\hline 2012 & 1,105 & 3,314815 & 1,710000 & 2,812 & 6,892203 \\
\hline 2013 & 1,020 & 3,580000 & 1,710000 & 3,108 & 7,554915 \\
\hline 2014 & 0,935 & 3,580000 & 1,603125 & 3,108 & 7,687458 \\
\hline
\end{tabular}

Sumber: Data diolah (2020)

Berdasarkan data pada Tabel 1 dan 2, diketahui bahwa kedua kelompok data memiliki banyaknya kelompok amatan $(r)$ dan banyaknya tahun amatan $(n)$ yang sama, yaitu $r=5$ dan $n=10$.

Setelah nilai $r$ dan $n$ diketahui, selanjutnya dihitung nilai dari rata-rata ekspektasi klaim masing-masing kelompok umur dengan menggunakan persamaan $\quad \bar{X}_{i}=\frac{\sum_{j=1}^{n} x_{i j}}{n}$. Berdasarkan data pada Tabel 1 diketahui bahwa kelompok polis pria memiliki $n$ (tahun) $=10$, dengan demikian diperoleh nilai rata-rata ekspektasi klaim masing-masing kelompok umur seperti yang tersaji pada Tabel 3.
Tabel 2. Besar Ekspektasi Klaim Selama 10 Tahun untuk Kelompok Polis Wanita (Juta Rupiah/Tahun)

\begin{tabular}{|c|c|c|c|c|c|}
\hline Tahun & $\begin{array}{c}\text { Umur } \\
\leq 30 \\
\text { Tahun }\end{array}$ & $\begin{array}{c}\text { Umur 31 - } \\
\text { 40 Tahun }\end{array}$ & $\begin{array}{c}\text { Umur } \\
41-50 \\
\text { Tahun }\end{array}$ & $\begin{array}{c}\text { Umur 51 } \\
-60 \\
\text { Tahun }\end{array}$ & $\begin{array}{c}\text { Umur }> \\
60 \text { Tahun }\end{array}$ \\
\hline 2005 & 0,35 & 0,501563 & 0,25 & 0,742857 & 0,780469 \\
\hline 2006 & 1,12 & 1,203750 & 0,30 & 5,645714 & 11,55094 \\
\hline 2007 & 1,40 & 1,103438 & 0,20 & 2,971429 & 8,897344 \\
\hline 2008 & 2,59 & 1,404375 & 0,20 & 3,120000 & 10,30219 \\
\hline 2009 & 1,96 & 1,905938 & 0,45 & 3,417143 & 10,92656 \\
\hline 2010 & 0,98 & 2,307188 & 0,55 & 3,120000 & 11,08266 \\
\hline 2011 & 0,77 & 2,608125 & 0,45 & 2,971429 & 11,86313 \\
\hline 2012 & 0,63 & 2,909063 & 0,50 & 2,971429 & 12,33141 \\
\hline 2013 & 0,56 & 3,310313 & 0,55 & 3,268571 & 11,08266 \\
\hline 2014 & 0,56 & 3,410625 & 0,60 & 3,268571 & 10,30219 \\
\hline
\end{tabular}

Sumber: Data diolah(2020)

Tabel 3. Rata-rata Ekspektasi Klaim Masing-masing Kelompok Umur Pria

\begin{tabular}{|c|c|}
\hline Kelompok Umur & $\bar{X}_{i}$ Pria \\
\hline$\leq 30$ Tahun & 1,343000 \\
\hline 31-40 Tahun & 2,943556 \\
\hline 41-50 Tahun & 1,688625 \\
\hline 51-60 Tahun & 2,930400 \\
\hline >60 Tahun & 6,481322 \\
\hline
\end{tabular}

Sumber : Data diolah (2020)

Setelah nilai rata-rata ekspektasi klaim masing-masing kelompok umur diketahui, dan berdasarkan Tabel 1 diketahui bahwa kelompok polis pria memiliki $r$ (banyak kelompok umur $)=5$, maka nilai rata-rata keseluruhan ekspektasi klaim kelompok polis pria dapat dihitung sebagai berikut:

$$
\begin{aligned}
\hat{\mu}=\bar{X}= & \frac{\sum_{i=1}^{r} \bar{X}_{i}}{r} \\
= & \frac{1}{5}(1,343000+2,943556+ \\
& 1,688625+2,930400+ \\
& 6,481322) \\
= & 3,077381
\end{aligned}
$$

Dengan demikian, diperoleh nilai rata-rata keseluruhan ekspektasi klaim kelompok polis pria adalah 3,077381 .

Selanjutnya, untuk kelompok polis wanita berdasarkan Tabel 2, dapat dilihat bahwa kelompok polis wanita memiliki banyaknya kelompok amatan $(r)$ dan banyaknya tahun amatan $(n)$ yang sama dengan kelompok polis pria. Oleh karena itu, perhitungan untuk 
kelompok polis wanita analog dengan perhitungan nilai rata-rata ekspektasi klaim untuk kelompok polis pria. Dengan demikian, diperoleh nilai rata-rata ekspektasi klaim masing-masing kelompok umur untuk kelompok polis wanita seperti yang tersaji pada Tabel 4 .

Tabel 4. Rata-rata Masing-Masing Kelompok Umur Wanita

\begin{tabular}{|c|c|}
\hline Kelompok Umur & $\hat{v}_{i}$ Wanita \\
\hline$\leq 30$ Tahun & 0,504373 \\
\hline 31-40 Tahun & 0,999999 \\
\hline 41-50 Tahun & 0,023583 \\
\hline 51-60 Tahun & 1,357764 \\
\hline > 60 Tahun & 11,203958 \\
\hline
\end{tabular}

Sumber : Data diolah (2020)

Diperoleh pula nilai rata-rata keseluruhan ekspektasi klaim kelompok polis wanita adalah 3,325021 .

Langkah selanjutnya yaitu mengestimasi nilai harapan dari variansi proses, untuk dapat menghitung nilai harapan dari variansi proses masing-masing kelompok polis, terlebih dahulu dihitung nilai variansi proses dari masingmasing kelompok umur pria dan wanita.

Sebelum menghitung nilai dari variansi proses masing-masing kelompok umur dari kelompok polis pria, perlu diketahui bahwa secara umum variansi proses menyatakan variansi frekuensi jumlah klaim keseluruhan pada kombinasi individual dan karakteristikkarakteristik risiko, hal ini disampaikan oleh Herzog (1996). Dengan menggunakan rumus $\hat{v}_{i}=\frac{1}{n-1} \sum_{j=1}^{n}\left(X_{i j}-\bar{X}_{l}\right)^{2}, \quad$ variansi proses dihitung dan hasil perhitungan disajikan pada Tabel 5.

Tabel 5. Besar Variansi Proses Untuk Masingmasing Kelompok Umur Pria

\begin{tabular}{|c|c|}
\hline Kelompok Umur & $\hat{v}_{i}$ Pria \\
\hline$\leq 30$ Tahun & 0,306340 \\
\hline 31-40 Tahun & 0,921234 \\
\hline 41-50 Tahun & 0,205093 \\
\hline 51-60 Tahun & 1,108829 \\
\hline > 60 Tahun & 4,561494 \\
\hline
\end{tabular}

Sumber: Data diolah (2020)

Setelah nilai variansi proses masing-masing kelompok umur diketahui, maka besar nilai harapan dari variansi proses kelompok polis pria dapat dihitung dengan menggunakan persamaan $\hat{v}=\frac{1}{r} \sum_{i=1}^{r} \widehat{v}_{l}$.

$$
\begin{aligned}
\hat{v}_{P}= & \frac{1}{5}(0,306340+0,921234+ \\
& 0,205093+1,108829+ \\
& 4,561494) \\
= & \frac{7,10299}{5} \\
= & 1,420598
\end{aligned}
$$

Jadi diperoleh besar nilai harapan dari variansi proses kelompok polis pria adalah 1,420598.

Perhitungan variansi proses untuk kelompok polis wanita analog dengan perhitungan variansi proses untuk kelompok polis pria. Sehingga diperoleh hasil perhitungan variansi proses masing-masing kelompok umur seperti pada Tabel 6.

Tabel 6. Besar Variansi Proses Untuk Masingmasing Kelompok Umur Wanita

\begin{tabular}{|c|c|}
\hline Kelompok Umur & $\bar{X}_{i}$ Wanita \\
\hline$\leq 30$ Tahun & 1,092000 \\
\hline 31-40 Tahun & 2,066437 \\
\hline 41-50 Tahun & 0,405000 \\
\hline 51-60 Tahun & 3,149714 \\
\hline >60 Tahun & 9,911953 \\
\hline
\end{tabular}

Sumber: Data diolah (2020)

Lebih lanjut lagi, diperoleh besar nilai harapan dari variansi proses kelompok polis wanita adalah 2,817935.

Setelah diketahui nilai rata-rata dari masing-masing kelompok umur, nilai rata-rata keseluruhan kelompok polis dan nilai harapan dari variansi proses, maka langkah selanjutnya adalah mengestimasi variansi dari rata-rata keseluruhan ekspektasi klaim kelompok polis.

Besar variansi dari rata-rata keseluruhan ekspektasi klaim kelompok polis pria dapat diestimasi sebagai berikut:

$$
\begin{aligned}
\hat{a}= & \frac{1}{r-1} \sum_{i=1}^{r}\left(\bar{x}_{i}-\bar{X}\right)-\frac{\bar{v}}{n} \\
= & \frac{1}{4}\left[(1,343000-3,077381)^{2}+\right. \\
& (2,943556-3,077381)^{2}+ \\
& (1,688625-3,077381)^{2}+ \\
& (2,930400-3,077381)^{2}+ \\
& \left.(6,481322-3,077381)^{2}\right]- \\
& \frac{1}{10}(1,420598) \\
= & \frac{16,56305}{4}-\frac{1,420598}{10}
\end{aligned}
$$




$$
=3,998702
$$

Jadi, diperoleh besar variansi dari rata-rata keseluruhan ekspektasi klaim kelompok polis pria adalah 3,998702 .

Perhitungan besar variansi dari rata-rata keseluruhan ekspektasi klaim kelompok polis wanita analog dengan perhitungan untuk kelompok polis pria. Dengan demikian, diperoleh besar variansi rata-rata keseluruhan ekspektasi klaim dari kelompok polis wanita adalah 14,34704 .

Langkah selanjutnya adalah mengestimasi harga premi risiko untuk tahun 2015 dengan menggunakan persamaan $\hat{C}=\hat{Z} \bar{X}_{i}+(1-\hat{Z}) \mu$. Sesuai dengan persamaan tersebut, terlebih dahulu harus ditentukan besar faktor kredibilitas $(\hat{Z})$.

Faktor kredibilitas $\hat{Z}$ dihitung dengan menggunakan persamaan $\hat{Z}=\frac{n}{n+\widehat{K}}$. Sesuai dengan persamaan tersebut, faktor kredibilitas dapat dihitung jika nilai dari parameter kredibilitas $(\widehat{K})$ telah diketahui. Oleh karena itu, terlebih dahulu akan ditentukan nilai parameter kredibilitas $(\widehat{K})$ untuk kelompok polis pria.

$$
\begin{aligned}
\widehat{K}_{P} & =\frac{\hat{v}_{P}}{\hat{a}_{P}} \\
& =\frac{1,420598}{0,355265} \\
& =0,355265
\end{aligned}
$$

Jadi, diperolah nilai parameter kredibilitas untuk kelompok polis pria adalah 0,355265.

Setelah nilai dari parameter kredibilitas diketahui, selanjutnya dihitung besar faktor kredibilitas untuk kelompok polis pria sebagai berikut:

$$
\begin{aligned}
\hat{Z}_{P} & =\frac{n}{n+\widehat{K}_{P}} \\
& =\frac{10}{10+0,355265} \\
& =\frac{10}{10,355265} \\
& =0,965692
\end{aligned}
$$

Jadi, didapat besar faktor kredibilitas untuk kelompok polis pria adalah 0,965692.

Setelah besar faktor kredibilitas diperoleh, maka harga premi risiko tahun 2015 untuk masing-masing kelompok umur dari kelompok polis pria dapat diestimasi. Besar estimasi harga premi risiko untuk kelompok umur $\leq 30$ tahun dari kelompok polis pria diestimasi sebagai berikut:

$$
\begin{aligned}
\hat{C}_{\leq 30 P}= & \left(\hat{Z}_{P}\right)\left(\bar{X}_{\leq 30 P}\right)+\left(1-\hat{Z}_{P}\right) \bar{X}_{P} \\
= & (0,965692)(1,343)+(1- \\
& 0,965692)(3,077381)
\end{aligned}
$$

$$
\begin{aligned}
= & \\
& 1,296925+ \\
& (0,034308)(3,077381) \\
= & 1,296925+0,105578 \\
= & 1,402503
\end{aligned}
$$

Untuk kelompok umur lainnya dihitung dengan langkah yang sama. Secara lengkap, besar estimasi premi risiko kelompok polis pria disajikan dalam Tabel 7.

Tabel 7. Estimasi Harga Premi Risiko Kelompok Polis Pria Tahun 2015 (Jutaan Rupiah/Tahun)

\begin{tabular}{|c|c|}
\hline Kelompok Umur & Pria \\
\hline$\leq 30$ Tahun & 1,402503 \\
\hline $31-40$ Tahun & 2,948147 \\
\hline $41-50$ Tahun & 1,73627 \\
\hline 51-60 Tahun & 2,935443 \\
\hline$>60$ Tahun & 6,364541 \\
\hline
\end{tabular}

Sumber: Data diolah (2020)

Perhitungan untuk kelompok polis wanita analog dengan perhitungan untuk kelompok polis pria, dengan demikian diperoleh parameter kredibilitas untuk kelompok polis wanita sebesar 0,196412 dan besar faktor kredibilitas untuk kelompok polis wanita sebesar 0,980737.

Lebih lanjut lagi, hasil estimasi harga premi risiko untuk kelompok polis wanita disajikan dalam Tabel 8.

Tabel 8. Estimasi Harga Premi Risiko Kelompok Polis Wanita Tahun 2015 (Jutaan Rupiah/Tahun)

\begin{tabular}{|c|c|}
\hline Kelompok Umur & Wanita \\
\hline$\leq 30$ Tahun & 1,135014 \\
\hline 31 - 40 Tahun & 2,090681 \\
\hline 41 - 50 Tahun & 0,461248 \\
\hline 51-60 Tahun & 3,153091 \\
\hline$>60$ Tahun & 9,78507 \\
\hline
\end{tabular}

Sumber: Data diolah (2020)

\section{KESIMPULAN DAN SARAN}

\subsection{Kesimpulan}

Pada penelitian ini diperoleh kesimpulan yaitu estimasi harga premi risiko asuransi penyakit kritis tahun 2015 masing-masing memiliki besaran yang berbeda untuk tiap kelompok umur pria dan wanita, yang 
dipengaruhi oleh nilai duga rata-rata yang berbeda tiap kelompok umur.

\subsection{Saran}

Penelitian selanjutnya yang akan mengestimasi harga premi risiko dengan menerapkan model EBCT, penulis menyarankan untuk melakukan penelitian mengenai asuransi kerugian. Namun, bila tertarik melakukan penelitian dengan menerapkan metode Bayes dan kredibilitas jenis lainnya, dapat menggunakan metode kredibilitas fluktuasi atau metode analisis Bayes.

\section{DAFTAR PUSTAKA}

Chukwudum, Q. (2018). Credibility Premium Estimation of Insurance Claims in Nigeria. HAL Archives-Ouvertes, 1-14.

Herzog, T. N. (1996). Introduction to Credibility Theory (Second Edi). Winsted: ACTEX.

Mueller, E., \& Spencer, L. (2012). A Guide to Critical Illness Insurance.

Pham, M. H. (2014). Survival Analysis - Breast Cancer. Undergraduate Journal of Mathematical Modeling: One + Two, 6(1), $1-27$.
Riset Kesehatan Dasar. (2018). Laporan Kesehatan Nasional. Badan Penelitian dan Pengembangan Kesehatan Departemen Kesehatan, Republik Indonesia.

Sembiring, R. K. (1986). Buku Materi Pokok Asuransi I Modul 1-9. s.1: Universitas Terbuka.

Sheta, O. E., \& Eldeen, A. N. (2012). Building A Health Care Data Warehouse For Cancer Diseases. International Journal of Database Management Systems (IJDMS), 4(5), $39-46$. https://doi.org/10.5121/ijdms.2012.4503

Sukono, Suyudi, M., Islamiyati, F., \& Supian, S. (2017). Estimation model of life insurance claims risk for cancer patients by using Bayesian method Estimation model of life insurance claims risk for cancer patients by using Bayesian method. IOP Conference Series: Materials Science and Engineering. https://doi.org/10.1088/17426596/755/1/011001

World Health Organization. (2013). Laporan Kesehatan Dunia. Genewa: WHO. 